Volume. 3 Nomor. 2

Periode: Juli - Desember 2019; hal. 64-69

p-ISSN : 2580-1112; e-ISSN : 2655-6669

Copyrighr @2019

Penulis memiliki hak cipta atas artikel ini

journal homepage: https://ejournal.akperfatmawati.ac.id

Jurnal Ilmiah Keperawatan Orthopedi

(JIKO)

\title{
Penanganan Anemia Pada Ibu Hamil dengan Pemberian Edukasi dan Suplementasi Tablet Besi
}

\author{
Lisnawati Nur Farida ${ }^{1}$, Vivi Maulida Solihah ${ }^{2}$ \\ Akademi Keperawatan Fatmawati, Jakarta
}

\begin{abstract}
Abstrak
Anemia pada ibu hamil berdampak pada kejadian abortus, persalinan prematuritas, hambatan tumbuh kembang janin, perdarahan antepartum, dan ketuban pecah dini. Pemerintah telah memprogramkan pemberian tablet Fe pada setiap bu hamil, namun upaya ini tidak didukung dengan pengetahuan ibu mengenai nutrisi seimbang dan pentingnya suplementasi tablet Fe. Tujuan penelitian ini adalah untuk meningkatkan kadar hemoglobin pada ibu hamil, melalui pemberian edukasi nutrisi seimbang dan suplementasi tablet Fe. Penelitian ini merupakan penelitian deskriptif dengan rancangan studi kasus pada dua orang ibu hamil dengan anemia. Setelah diberikan edukasi terstruktur dan pemantauan konsumsi tablet Fe selama 4 minggu, ibu melakukan pemerikasaan kadar $\mathrm{Hb}$. Didapatkan hasil setelah diberikan edukasi dan suplementasi tablet Fe, kedua subjek mengalami peningkatan pengetahuan dan peningkatan kadar $\mathrm{Hb}$. Pengetahuan subjek I meningkat dari kategori kurang menjadi cukup, dan subjek II meningkat dari kategori kurang menjadi baik. Peningkatan kadar Hb pada subjek I dari $10.3 \mathrm{~g} / \mathrm{dl}$ menjadi $11.6 \mathrm{~g} / \mathrm{dl}$ dan pada subjek II dari $10.9 \mathrm{~g} / \mathrm{dl}$ menjadi $12.9 \mathrm{~g} / \mathrm{dl}$. Untuk itu perlu adanya pemberian edukasi nutrisi seimbang dan pemantauan konsumsi tablet $\mathrm{Fe}$ dalam upaya penanganan anemia pada ibu hamil.
\end{abstract}

Kata Kunci: Anemia, Ibu Hamil, Edukasi Nutrisi, Tablet Besi

\begin{abstract}
Anemia in pregnant women has an impact on the incidence of abortion, labor prematurity, fetal growth and development obstacles, antepartum bleeding, and premature rupture of membranes. The government has programmed the administration of iron tablets to every pregnant woman, but this effort is not supported by maternal knowledge about balanced nutrition and the importance of supplementing iron tablets. The purpose of this research is to increase hemoglobin levels in pregnant women, through providing balanced nutrition education and iron tablets supplementation. This research is a descriptive study with a case study design in two pregnant women with anemia. After being given structured education and monitoring of iron tablet consumption for 4 weeks, the mother carries out $\mathrm{Hb}$ levels examination. Obtained results after being given education and supplementation of iron tablets, both subjects experienced increased knowledge and increased Hb levels. The knowledge of subject I increased from less to sufficient categories, and subject II increased from less to good categories. Increased Hb levels in subject I from $10.3 \mathrm{~g} / \mathrm{dl}$ to $11.6 \mathrm{~g} \mathrm{dl}$ and in subject II from $10.9 \mathrm{~g}$ dl to $12.9 \mathrm{~g} / \mathrm{dl}$. For this reason it is necessary to
\end{abstract}

1,2 e-mail: lisnawati.nurfarida@akperfatmawati.ac.id 
provide balanced nutrition education and monitoring of Fe tablet consumption in an effort to treat anemia in pregnant women.

Keywords: Anemia, Pregnant Women, Nutrition Education, Iron Tablet

\section{Pendahuluan}

Proporsi kejadian anemia pada ibu hamil di usia produktif semakin tinggi. Berdasarkan hasil Riskesdas tahun 2018, kejadian anemia pada ibu hamil tertinggi adalah pada usia 15-24 tahun sebesar 84,6\% disusul oleh ibu usia 25-34 tahun sebesar $33,7 \%$. Anemia pada ibu hamil sangat berkaitan dengan mortalitas dan morbiditas pada ibu dan bayi, termasuk risiko keguguran, kematian perinatal, prematuritas dan Berat Bayi Lahir Rendah (BBLR) (WHO, 2012).

Kejadian anemia pada ibu hamil sering disebabkan karena defisiensi zat besi. Anemia defisiensi besi ini disebabkan karena kurangnya unsur zat besi pada makanan, pola makan yang salah, gangguan absorpsi, atau terlampau banyaknya zat besi yang keluar dari tubuh sehingga kadar hemoglobin $(\mathrm{Hb})$ ibu berkurang dari $11 \mathrm{~g} / \mathrm{dl}$ pada trimester 1 dan trimester 3 , serta $\leq 10,5 \mathrm{~g} / \mathrm{dl}$ pada trimester 2 (Lowdermilk, Perry, \& Cashion, 2013).

Anemia pada kehamilan tidak dapat dipisahkan dengan perubahan fisiologis yang terjadi selama proses kehamilan, umur janin, dan kondisi ibu hamil sebelumnya. Pada saat hamil, tubuh akan mengalami perubahan yang signifikan, jumlah darah dalam tubuh meningkat sekitar $20-30 \%$, sehingga tubuh memerlukan tambahan pasokan zat besi dan vitamin untuk membuat hemoglobin (Astriana, 2017).

Upaya pencegahan dan penanggulangan anemia telah dilakukan oleh pemerintah dan telah distandardisasi melalui Peraturan Menteri Kesehatan Republik Indonesia No.88 tahun 2014 tentang standar tablet tambah darah pada wanita usia subur dan ibu hamil. Upaya ini tidak hanya mencakup pemberian tablet besi selama masa kehamilan atau minimal 90 tablet, tetapi juga menegaskan pentingnya konseling, informasi dan edukasi.

Hasil Riskesdas tahun 2018 menunjukkan bahwa sebagian besar ibu hamil telah mendapat tablet besi. Namun hanya sekitar $24 \%$ yang mendapat tablet besi sebanyak $\geq 90$ butir sisanya hanya mendapat < 90 butir. Tingkat konsumsi tablet besi juga masih cukup rendah. Hanya sebesar 38,1\% ibu hamil yang mengkonsumsi tablet besi sebanyak $\geq 90$ butir, sisanya $61,9 \%$ hanya mengkonsumsi tablet besi sebanyak $<90$ butir.

Berdasarkan studi pendahuluan, kondisi serupa ditemui di Puskesmas Kecamatan Pancoran, dimana masih dijumpai ibu hamil dengan anemia yang tidak patuh terhadap konsumsi tablet besi, dan belum memahami pentingnya konsumsi tablet besi selama masa kehamilannya meskipun pihak puskesmas telah memberikan konseling, informasi dan edukasi.

Menurut Sulistyaningsih dan Yuliyanti (2017), untuk mengatasi anemia pada ibu hamil diperlukan suatu upaya tambahan yaitu edukasi mengenai gizi pada ibu hamil dengan anemia yang terbukti dapat meingkatkan kadar hemoglobin ibu. Sehingga besardarkan kondisi tersebut, perlu dilakukan penelitian untuk mengetahui apakah pemberian edukasi nutrisi dan suplementasi tablet besi dapat mengatasi anemia pada ibu hamil di Puskesmas Pancoran?

\section{Metode}

Penelitian ini merupakan penelitian deskriptif dengan metode studi kasus. Penelitian ini melibatkan 2 orang ibu 
hamil dengan anemia yang ditemui pada saat kunjungan antenatal, dengan kriteria inklusi meliputi ibu dengan kadar $\mathrm{Hb}<10$ g/dl, usia kehamilan < 36 minggu. Sedangkan kriteria eksklusi yaitu ibu hamil dengan anemia karena penyebab lain seperti anemia megaloblastik, anemia hipoplastik, atau anemia hemolitik; ibu hamil dengan penyakit kronis; ibu hamil yang mengkonsumsi kortikosteroid; serta ibu hamil yang tidak bersedia dilakukan follow-up secara rutin.

Sebelum pengambilan data, subjek diberikan informed consent, dan peneliti menjamin kerahasiaan data yang diberikan oleh subjek. Selanjutnya, peneliti memberikan edukasi berupa diit seimbang pada ibu hamil dengan anemia.

Sebelum dan sesudah diberikan edukasi, subjek studi kasus diukur tingkat pengetahuannya menggunakan kuesioner. Selanjutnya, pemantauan konsumsi tablet besi dilakukan selama 30 hari menggunakan lembar observasi yang diisi secara mandiri oleh subjek dan dimonitor setiap minggu oleh peneliti. Di akhir minggu ke 4, kadar hemoglobin diukur kembali di laboratorium Puskesmas Kecamatan Pancoran.

\section{Hasil}

Dalam kasus ini dilibatkan 2 orang ibu hamil dengan anemia sebagai subjek studi kasus dengan karakteristik yang akan dijabarkan dalam tabel berikut ini.

Tabel-1 Karakteristik Subjek Studi Kasus

\begin{tabular}{clcl}
\hline No & Karakteristik & \multicolumn{1}{c}{ Subjek I } & Subjek II \\
\hline 1 & Usia ibu & 21 Tahun & 24 Tahun \\
2 & Usia & 32 minggu & 35 minggu 5 \\
& kehamilan & & hari \\
3 & Paritas & Multigravida & Primigravida \\
4 & Pendidikan & SMA & SMA \\
5 & Pekerjaan & Ibu Rumah & Karyawan \\
& & Tangga & Swasta
\end{tabular}

Pada table-1 dijelaskan bahwa subjek 1 Ny.K berusia 21 tahun, usia kehamilan 32 minggu, kehamilan multigravida, anak pertama telah berusia 1.5 tahun dengan jenis kelamin laki-laki.

Pendidikan terakhir Ny. K yaitu SMA, status pekerjaan adalah seorang ibu rumah tangga dan berasal dari suku Betawi. Subjek 2 Ny.V berusia 24 tahun, usia kehamilan 35 minggu 5 hari dan merupakan kehamilan pertama. Pendidikan terakhir Ny. V yaitu SMA, sebelum hamil bekerja sebagai karyawan swasta namun saat ini telah mengambil cuti dan berasal dari suku Jawa.

\section{Pengkajian dilakukan pada kedua} subjek dengan hasil sebagai berikut:

Keluhatan utama yang dirasakan subjek 1 adalah badannya terasa cepat lelah dan lemas, sering merasakan pusing ketika setelah aktivitas, subjek mengatakan kurang nafsu makan karena sering merasa mual, sejak usia kehamilan 7 bulan.

Hasil pemeriksaan kadar $\mathrm{Hb} 10.3$ $\mathrm{g} / \mathrm{dl}$, subjek dianjurkan dari puskesmas untuk meminum tablet penambah darah $(\mathrm{Fe})$ setiap pemeriksaan diberikan sebanyak 30 tablet diminum sebelum tidur. Ketika dilakukan observasi keadaan subjek wajah tampak terlihat lemas, membran mukosa lembab, turgor kulit elastis, ekspresi wajah tampak, lesu dan lelah, kuku tampak pucat.

Ketika dilakukan pemeriksaan fisik konjungtiva pucat/anemis, CRT $<3$ detik, TD: $110 / 70 \mathrm{mmHg}, \mathrm{N}: 88 \mathrm{x} / \mathrm{menit}, \mathrm{RR}$ : 20x/menit. Asupan makan selama hamil yang dikonsumsi yaitu sayur sop, hati ayam, baso, nasi goreng, mie dan terkadang diselingi buah. Tidak mengalami penurunan berat badan. Subjek merasa malas untuk meminum tablet besi karena adanya rasa mual.

Subyek I mengatakan sebelumnya pernah mendapatkan pengetahuan dari bidan Puskesmas mengenai nutrisi seimbang pada ibu hamil, namun subyek I masih belum terlalu memahaminya.

Keluhan yang dirasakan oleh subjek 2 adalah sering merasa lemas, merasa pusing ketika beranjak dari duduk ke berdiri mata terasa berkurang-kunang dan 
gelap, mudah mengantuk, serta nafsu makan menurun. Subjek mengatakan sebelum hamil telah menderita anemia, saat ini kadar $\mathrm{Hb} 10.9 \mathrm{~g} / \mathrm{dl}$, dan mendapatkan vitamin tablet besi sebanyak 30 tablet yang diminum setiap pagi dan malam hari.

Ketika dilakukan observasi keadaan subyek membran mukosa kering, turgor kulit elastis, ekspresi wajah subyek terlihat lemas dan letih, kuku tampak pucat, ketika duduk di lantai harus diganjal oleh bantal karena tidak kuat duduk lama.

Hasil pemeriksaan fisik konjungtiva pucat/anemis, CRT <3 detik, TD: 90/78 mmHg, N: 92 x/menit, RR: 18x/menit, warna kulit pucat, akral hangat. Asupan makan selama hamil yang dikonsumsi yaitu makanan seadanya terkadang sayur, ayam, tempe, tahu, dan telor sering diselingi buah-buahan. Nafsu makan mengalami penurunan hanya menghabiskan $1 / 2$ porsi, dengan $\mathrm{BB} 58$ $\mathrm{kg}$.

Subyek mengatakan lupa untuk meminum tablet $\mathrm{Fe}$ secara rutin, jika tidak ada yang memotivasi. Subyek mengatakan belum terlalu memahami tentang nutrisi yang seimbang pada ibu hamil dengan anemia.

Berdasarkan dari hasil pengkajian yang dilakukan pada kedua subjek diatas dapat ditegakkan diagnosa keperawatan ketidakseimbangan nutrisi kurang dari kebutuhan tubuh berhubungan dengan kurang pengetahuan dasar tentang nutrisi seimbang pada ibu hamil dengan anemia.

Intervensi keperawatan diberikan berupa edukasi mengenai diit seimbang pada ibu hamil dengan anemia, dilanjutkan dengan pemantauan konsumsi tablet besi selama 30 hari, dan mengukur kadar $\mathrm{Hb}$ ibu setelah 30 hari.

Berikut ini hasil perubahan tingkat pengetahuan ibu sebelum dan sesudah diberikan edukasi diit seimbang pada ibu hamil.
Tabel-2 Tingkat pengetahuan ibu sebelum dan sesudah diberikan edukasi

\begin{tabular}{ccccc}
\hline $\begin{array}{c}\text { Inisial } \\
\text { Subjek }\end{array}$ & \multicolumn{2}{c}{ Pre test } & \multicolumn{2}{c}{ Post test } \\
\hline & Skor & Kategori & Skor & Kategori \\
\hline $\begin{array}{c}\text { Subjek } \\
\text { I } \\
\begin{array}{c}\text { Subjek } \\
\text { II }\end{array}\end{array}$ & 10 & Kurang & 14 & Cukup \\
\hline
\end{tabular}

Berdasarkan table-2 ibu hamil mengalami peningkatan pengetahuan setelah diberikan edukasi. Pengetahuan subjek 1 mengalami peningkatan dari kategori kurang menjadi cukup, sedangkan pengetahuan subjek 2 meningkat dari kategori kurang menjadi baik.

Perubahan kadar $\mathrm{Hb}$ setelah dilakukan pemantauan minum tablet besi selama 30 hari pada subjek penelitian adalah sebagai berikut:

Tabel-3 Perubahan kadar $\mathrm{Hb}$ setelah konsumsi tablet besi selama 30 hari

\begin{tabular}{ccc}
\hline \multirow{2}{*}{ Subjek } & \multicolumn{2}{c}{ Kadar Hb } \\
& Sebelum & Sesudah \\
\hline Subjek 1 & $10,3 \mathrm{~g} / \mathrm{dl}$ & $11,6 \mathrm{~g} / \mathrm{dl}$ \\
Subjek 2 & $10,9 \mathrm{~g} / \mathrm{dl}$ & $12,9 \mathrm{~g} / \mathrm{dl}$ \\
\hline
\end{tabular}

Berdasarkan table-3 terlihat pada kedua subjek mengalami peningkatan kadar $\mathrm{Hb}$ setelah diberikan suplementasi tablet besi selama 30 hari. Peningkatan kadar $\mathrm{Hb}$ pada subjek 1 sebesar 1,3 g/dl sedangkan pada subjek $2 \mathrm{Hb}$ meningkat sebesar $2 \mathrm{~g} / \mathrm{dl}$ dalam waktu 30 hari.

\section{Pembahasan}

Hasil studi kasus pada kedua subjek menunjukkan bahwa subjek 2 mengalami kenaikan skor pengetahuan yang lebih baik dibandingkan subjek 1. Begitu pula untuk peningkatan kadar $\mathrm{Hb}$ pada subjek 2 lebih tinggi dibandingkan subjek 1 .

Hal ini dapat disebabkan karena beberapa kondisi, diantaranya karena faktor usia. Dilihat dari usia subjek 1 lebih muda dibandingkan subjek 2 . Menurut Waty, Febry, \& Rahmiwati (2016), ibu yang berusia lebih muda 
cenderung minim perhatian terhadap kehamilan serta kurang motivasi untuk mengetahui pemenuhan kebutuhan gizi seimbang selama kehamilan. Berbeda dengan subjek 2 dengan usia yang lebih matang, sudah mampu mengambil keputusan sendiri, mental fisik dan psikis dalam dirinya sudah terbentuk secara optimal, sehingga diusianya yang sekarang mudah menangani keguncangan dalam pikirannya, dan cukup mengoptimalkan rasa perhatiannya terhadap kehamilan yang sekarang.

Selain karena faktor usia, hal yang cukup berbeda dari kedua subjek adalah paritas. Subjek 1 merupakan multigravida dengan jarak kehamilan 1,5 tahun dengan anak sebelumnya, sedangkan subjek 2 merupakan ibu primigravida.

Hasil survey menunjukkan kejadian anemia pada ibu multigravida lebih tinggi dibandingkan dengan ibu primigravida. Diperberat dengan jarak antar kehamilan yang cukup dekat, menjadikan ibu multigravida semakin berpeluang mengalami anemia. Jarak kehamilan risiko rendah yaitu jika ibu melahirkan bayi $\geq 2$ tahun sampai 10 tahun, sedangkan jarak kehamilan risiko tinggi jika ibu memiliki jarak $<2$ tahun atau $\geq$ 10 tahun (Nurhidayah, 2013). Jarak kehamilan yang terlalu dekat untuk seorang ibu dapat meningkatkan kejadian anemia karena status gizi ibu belum pulih, selain itu seorang ibu bisa berisiko mengalami infeksi, ketuban pecah dini dan pendarahan (Krisnadi, 2015).

Peningkatan kadar $\mathrm{Hb}$ pada kedua subjek selaras dengan penignkatan pengetahuan. Hal ini sesuai dengan hasil penelitian sebelumnya yang menyatakan pengetahuan adalah domain yang sangat penting untuk terbentuknya tindakan yang dilakukan seseorang.

Berdasarkan pengalaman dan pendidikan ternyata tindakan yang didasari oleh pengetahuan akan lebih secara teratur dari pada tindakan yang tidak disadari. Pengetahuan tentang gizi dapat mencegah seseorang dari konsumsi makanan yang salah, maka dengan tingkat pengetahuan yang baik ibu hamil dapat mengetahui bahan pangan yang seimbang yang tidak membahayakan kehamilan (Iswanto, 2012).

Menurut penelitian Purwaningrum (2017), pengetahuan ibu hamil tentang pentingnya gizi selama kehamilannya merupakan faktor yang menyebabkan perilaku ibu hamil dalam menerapkan variasi makanan yang bergizi selama kehamilannya.

Oleh karena itu, seseorang dengan pengetahuan rendah akan sulit berespon atau mencoba sesuatu yang baru karena yang terbayang hanya rasa takut salah dan pengetahuan yang rendah juga merupakan faktor penghambat untuk menerima suatu motivasi termasuk dalam bidang kesehatan.

Peningkatan pengetahuan pada subjek 2 cenderung lebih baik, yang dapat dipengaruhi oleh status pekerjaan, dibandingkan subjek 1 yang berstatus sebagai ibu rumah tangga. Pekerjaan sebagai ibu rumah tangga terdapat keterbatasan dalam mempunyai sosialisasi dan interaksi dibandingkan dengan ibu yang bekerja. Proses sosialisasi dan interaksi dapat mempengaruhi pengetahuan ibu tentang konsumsi tabelt Fe (Sulistiyanti, 2015). Struktur sosial dalam masyarakat seperti pekerjaan akan mempengaruhi seseorang dalam memanfaatkan pelayanan kesehatan.

Pekerjaan seseorang dapat mencerminkan sedikit banyaknya informasi yang diterima. Informasi tersebut akan membantu seseorang dalam mengambil keputusan untuk memanfaatkan pelayanan kesehatan yang ada (Irianto, 2018).

\section{Kesimpulan}

Anemia pada ibu hamil dalam studi kasus ini dapat diatasi dengan cara pemantauan konsumsi suplemen tablet besi yang disertai dengan edukasi untuk peningkatan pengetahuan ibu tentang pentingnya diit seimbang pada ibu hamil 
dengan anemia. Disarankan upaya ini dapat terus dilanjutkan sebagai strategi di Puskesmas dalam rangka menurunkan angka kejadian anemia pada kehamilan.

\section{Ucapan Terimakasih}

Ucapan terima kasih disampaikan kepada pihak Puskesmas Kecamatan Pancoran yang telah memfasilitasi dan mendukung kelancaran penelitian ini.

\section{Daftar Pusraka}

Astriana, W. (2017). Kejadian Anemia pada Ibu Hamil Ditinjau dari Paritas dan Usia. Jurnal Aisyah: Jurnal Ilmu Kesehatan.2 (2), 123-130. Diunduh dari https://media.neliti.com/media/publi cations/217394-kejadian-anemiapada-ibu-hamil-ditinjau.pdf

Irianto, S.S. (2018). Pengaruh Tingkat Kepatuhan Minum Tablet $\mathrm{Fe}$ Terhadap Kejadian Anemia Pada Ibu Hamil Trimester di Puskesmas Pejeruk, 2017. Jurnal Kedokteran Yarsi.

https://www.researchgate.net/public ation/331095738_Pengaruh_Tingkat _Kepatuhan_Minum_Tablet_Fe_Ter hadap_Kejadian_Anemia_Pada_Ibu _Hamil_Trimester_III_di_Puskesma s_Pejeruk_T ahun_2017

Iswanto, B. (2012). Hubungan Pengetahuan Ibu Hamil Tentang Anemia Defisiensi Besi dengan Kepatuhan Mengkonsumsi Tablet Besi Di Puskesmas Karangdowo Klaten. E- journal UMS. http://eprints.ums.ac.id/18537/9/NA SKAH_PUBLIKASI.pdf

Krisnadi. (2015). Prematuritas. Bandung: Refika Aditama Lowdermilk, D., Perry, S., Chasion, M.C. (2013). Keperawatan Maternitas edisi 8. Mosby.

Nurhidayati, R. (2013). Analisis Faktor Penyebab Terjadinya Anemia Pada Ibu Hamil Diwilayah Kerja Puskesmas Tawangsari Kabupaten Sukoharjo. E-Journal UMS. http://eprints.ums.ac.id/24138/12/02 NASKAH_PUBLIKASI.pdf

Purwaningrum, Y. (2017). Pengetahuan Ibu Hamil Tentang Gizi Dengan Kejadian Anemia Selama Kehamilan: Jurnal Kesehatan Vol. 5. No. 2. Diunduh dari https://publikasi.polije.ac.id/index.p hp/jurnal_kesehatan/article/view/47 $\underline{7 / 0}$

Riset Kesehatan Dasar (RISKESDAS). (2018). Hasil Utama Riskesdas 2018: Proporsi Anemia Ibu Hamil 2018. Kementerian Kesehatan Badan Penelitian dan Pengembangan Kesehatan: Jakarta. Sulistiyanti, A. (2015). Hubungan Tingkat Pengetahuan Ibu Hamil tentang Anemia dengan Kepatuhan Konsumsi Tabelt Fe di Wilayah Kerja Puskesmas Masaran 1 Sragen.Jurnal Kebidanan dan Ilmu Kesehatan Vol.2.

Sulistyaningsih \& Yuliyanti. (2017). Penatalaksanaan Pendidikan Kesehatan Diit Anemia Ibu Hamil dengan Masalah Ketidakseimbangan Nutrisi Kurang dari Kebutuhan Tubuh: Indonesian Jurnal On Medical Science (IJMS) Vol.4 No. 1 Januari 2017.

Wati, W., Febry, F., \& Rahmiwati, A. (2016). Faktor-faktor yang berhubungan dengan defisiensi zat besi pada ibu hamil di wilayah kerja puskesmas gandus Palembang. Jurnal Ilmu Kesehatan Masyarakat Vol.7. Diunduh dari https://media.neliti.com/media/publi cations/58004-ID-factors-of-irondeficiency-on-pregnant-w.pdf

WHO. (2012). Guideline: Daily iron and folic acid supplementation in pregnant women. Diunduh dari https://apps.who.int/iris/bitstream/ha ndle/10665/77770/9789241501996 eng.p df 